\title{
The Elaboration of a Practical Protocol for the Micropropagation of Several Apple Rootstock Varieties
}

\author{
Doina CLAPA $^{1 *}$, Alexandru FIRA ${ }^{2}$, Manuela SIMU ${ }^{1}$, Monica HÂRȚA ${ }^{1}$, Cristian SISEA ${ }^{1}$ \\ ${ }^{1}$ University of Agricultural Sciences and Veterinary Medicine Cluj-Napoca, Romania \\ ${ }^{2}$ Industrial Plants LTD., Kazanlak, Bulgaria, \\ *)Corresponding author, e-mail: doinaclapa@yahoo.com
}

BulletinUASVM Horticulture 73(2) / 2016

Print ISSN 1843-5254, Electronic ISSN 1843-5394

DOI:10.15835/buasvmcn-hort:12170

\begin{abstract}
The apple rootstock varieties 'MM 106/4', 'MM 106/6', 'D 18', 'D 20', 'JTE-H' and 'MR 09/4' were multiplied in vitro on modified Murashige and Skoog media gelled with wheat starch (MSs) and supplemented with $0.7 \mathrm{mg} / \mathrm{l}$ BA, which provided intense axillary shoot proliferation. Among the studied genotypes, 'MR 09/4' had the highest multiplication rate (19.56), followed by 'D18' (15.36). The lowest multiplication rates were recorded in 'MM 106/6' (5.36) and in 'MM 106/4' (3.32). The use of the technique of direct ex vitro rooting and acclimatization in floating perlite provided rooting percentages of more than $90 \%$.
\end{abstract}

Keywords: apple rootstocks, ex vitro rooting, floating perlite, wheat starch

\section{Introduction}

Several apple genotypes were successfully propagated in vitro; the first studies regarding apple rootstocks micropropagation were reported in the late 1960's (Dobránszky and Teixeira da Silva, 2010).

\section{Aims and objectives}

The aim of our research was to increase the effectiveness of the multiplication stage in some rootstock varieties by the use of simple culture media, with low cytokinin content, as well as to test the direct ex vitro rooting ability of the shoots obtained in the in vitro multiplication stage, for this purpose it is recommended to use the floating perlite method, which is radically new, simple and efficient (Clapa et al., 2013), in order to simplify and improve the micropropagation protocols for these rootstocks.

\section{Materials and methods}

For the experiments six apple rootstock genotypes were used: 'MM 106/4', 'MM 106/6', 'D 18', 'D 20', 'JTE-H' and 'MR 09/4'. The plant material was sourced from the Research Institute of Nyiregyhaza in Hungary and consisted of in vitro cultures in the multiplication stage. The culture medium was modified MS (Murashige and Skoog, 1962) abbreviated as MSs, containing MS salts, myo-inositol (100 mg L$\left.{ }^{-1}\right)$, thiamine-HCl (1 $\left.\mathrm{mg} \mathrm{L}{ }^{-1}\right)$, pyridoxine-HCl $\left(0.5 \mathrm{mg} \mathrm{L}^{-1}\right)$, nicotinic acid ( $0.5 \mathrm{mg} \mathrm{L}^{-1}$ ), $30 \mathrm{~g} \mathrm{~L}^{-1}$ sucrose as the carbon source, supplemented with $0.7 \mathrm{mg} / \mathrm{l} \mathrm{BA}$ and gelled with 50 $\mathrm{g} / \mathrm{l}$ wheat starch. The $\mathrm{pH}$ of the media was adjusted to 5.8 before adding the gelling agent. The explants consisted of shoot fragments $2 \mathrm{~cm}$ in length, containing 4-5 nodes. The leaves longer than 1 $\mathrm{cm}$ were excised. Five explants/culture vessel were used. The explants were inserted into the culture media in oblique position and, $2 / 3-3 / 4$ of the basal part of the microcuttings was immersed in the culture medium, in order to establish optimal contact between the microcuttings and the culture medium. The multiplication cycle was of 60 days. For each variety, five repetitions were used, each one consisted of one jar with five plantlets/experimental treatment, that is a total number of 25 plantlets/treatment.The in vitro 
Tab.1. The in vitro proliferation of the apple rootstocks on the standard culture medium (MSs + $0.7 \mathrm{mg} / \mathrm{l} \mathrm{BAP)}-60$ day old cultures. Average values/plant and standard errors are provided $( \pm)$

\begin{tabular}{cccccc}
\hline Variety & Plant height $(\mathrm{cm})$ & $\begin{array}{c}\text { Shoot no. } \\
\text { /vessel }\end{array}$ & $\begin{array}{c}\text { No. of shoots } \\
\geq 2 \mathrm{~cm}\end{array}$ & Proliferation rate Multiplication rate \\
\hline 'MM 106/4' & $4.65 \pm 0.28$ & $30.6 \pm 5.81$ & $26.8 \pm 5.05$ & $5.36 \pm 0.64$ & $7.04 \pm 0.91$ \\
\hline 'MM 106/6' & $4.80 \pm 0.29$ & $18.6 \pm 1.20$ & $16.6 \pm 1.02$ & $3.32 \pm 0.40$ & $4.56 \pm 0.59$ \\
\hline 'D 18' & $5.60 \pm 0.15$ & $118 \pm 4.93$ & $76.8 \pm 4.09$ & $15.36 \pm 1.1$ & $18.44 \pm 1.34$ \\
\hline 'D 20' & $5.47 \pm 0.19$ & $136.2 \pm 12.35$ & $67.2 \pm 5.49$ & $13.44 \pm 1.35$ & $16.64 \pm 1.66$ \\
\hline 'JTE-H' & $5.46 \pm 0.21$ & $50.2 \pm 3.38$ & $43.2 \pm 3.42$ & $8.64 \pm 0.78$ & $11.16 \pm 1.13$ \\
\hline 'MR 09/4' & $5.58 \pm 0.19$ & $130.8 \pm 12.47$ & $97.8 \pm 6.39$ & $19.56 \pm 1.64$ & $21.32 \pm 1.67$ \\
\hline
\end{tabular}

Tab. 2. Results regarding the direct ex vitro rooting of the axillary shoots resulted from the cultures on MSs media supplemented with $0.7 \mathrm{mg} / \mathrm{l} \mathrm{BA}$, in the rootstocks in our study. Average values/ plant and standard errors are provided $( \pm)$

\begin{tabular}{cccccc}
\hline Genotype & $\begin{array}{c}\text { Total no. of shoots } \\
\text { transferred }\end{array}$ & Rooting (\%) & Shoot length $(\mathrm{cm})$ & Root length (cm) & No. of roots \\
\hline 'JTE-H' & 219 & 93.6 & $3.09 \pm 0.27$ & $6.52 \pm 0.62$ & $12 \pm 1.76$ \\
\hline 'D 18' & 326 & 98.16 & $4.18 \pm 0.17$ & $6.30 \pm 0.64$ & $18 \pm 3.16$ \\
\hline 'D 20' & 272 & 93.01 & $3.5 \pm 0.33$ & $5.01 \pm 0.35$ & $12.8 \pm 1.74$ \\
\hline
\end{tabular}

cultures were incubated in the growth room at 16 hour photoperiod, $32.4 \mu \mathrm{mol} \mathrm{m}{ }^{-2} \mathrm{~s}^{-1}$ light intensity and temperature of $23 \pm 3^{\circ} \mathrm{C}, 50 \pm 2 \%$ humidity, Lighting was provided by Philips fluorescent tubes mounted horizontally above the shelves with the culture vessels. The in vitro culture period for the multiplication stage was 60 days. Rooting was carried out directly ex vitro in the same stage together with acclimatization, in the greenhouse, in July, by the floating perlite method (Clapa el al, 2013). No plant growth regulators were used for rooting.

\section{Results and Discussion}

In some genotypes ('D 20') a large number of sub-standard shoots shorter than $2 \mathrm{~cm}$ were regenerated. Among the genotypes studied, in 'MR $09 / 4$ ' the highest number of standard-sized shoots were regenerated, followed by ' $\mathrm{D} 18$ '. In genotypes 'MM 106/4'and 'MM 106/6'fewer shoots were regenerated, but those were long and vigorous; these rootstock genotypes yielded the highest percentages of standard-sized shoots. We consider that rootstock 'JTE-H' developed optimally in these conditions, having in view the relatively high number and percentage of standard shoots, as well as the height of regenerated plantlets. Considering the number of shoots $\geq 2 \mathrm{~cm}$, 'MR $09 / 4$ 'had the highest multiplication rate, followed by 'D 18' and 'D 20' (Tab. 1).

The ex vitro rooting and acclimatization percentages in floating perlite were over $90 \%$ in the three genotypes in our study (Tab. 2). The root mass was well developed. From each treatment, ten plants/culture vessel were investigated (a total number of 20 plants/treatment) in order to establish the average length of root clumps and the number of roots/plant. The average numbers of roots/plant were minimum 12 and the lengths of the root clumps were more than $5 \mathrm{~cm}$.

\section{Conclusion}

Our results show that in the in vitro multiplication stage the culture medium MS $+0.7 \mathrm{mg} / \mathrm{l} \mathrm{BA}$ is suitable for the micropropagation of the apple rootstocks in our study, especially 'MR 09/4', 'D 18 'and 'D 20'. Wheat starch at $50 \mathrm{~g} / \mathrm{l}$ concentration in the culture media proved to be an effective gelling agent for these apple rootstocks. For the 'JTE-H', 'D 18'and 'D 20'apple rootstocks direct ex vitro rooting in floating perlite ensured ex vitro rooting and acclimatization percentages above 90 $\%$. 


\section{REFERENCES}

1. Clapa D, Fira A, Joshee N (2013). An efficient ex vitro rooting and acclimatization method for horticul-tural plants using float hydroculture. HortScience 48(9): 11591167.
2. DobránszkyJ, Teixeira daSilvaJA(2010). Micropropagation of apple-a review. Biotechnol Adv 28:462-488.

3. Murashige T, Skoog F (1962). A revised medium for rapid growth and bioassays with tobacco tissue culture. Physiol Plantarum 15:473-497. 